\title{
ČLÁNKY
}

\section{Být legislativcem: Empirická šetření v administrativních fázích legislativy*}

\author{
Being a Legislator: Administrative Phase \\ of Legislation - Empirical Research
}

\author{
Martin Škop ${ }^{* *}$, Barbora Vacková***
}

\begin{abstract}
Abstrakt
Tento článek se soustredí na porovnáni výpovédí legislativnich expertui s teoretickými prǐstupy k tvorbè práva. Cilem je zmapovat jejich pojetí čnnosti, kterou provádèji, a která má vést ke vaniku právního prèdpisu. Cílem článku dále je prèdložit základni možné prǐstupy ke studiu procesu spjatjch s tvorbou práva, zejména s fárí, která probíhá na vládni úrovni, tj. v rámci byrokratickébo aparátu, kterým vláda, jako typický predkladatel návrbi právních prèdpisü, disponuje. Clánek proto kombinuje empirické postupy (kvalitativní

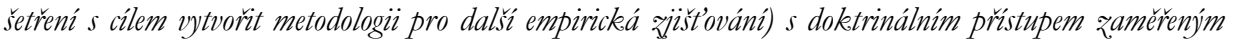
na analyzu dostupných literárnich poznatki, tedy s poznatky plynoucimi zodborné literatury.
\end{abstract}

\section{Klíčová slova}

Tvorba práva; empirický výzkum; prăprava návrbu právnich predpisu; kvalitativni výzkum; legislativa; jasykový víklad.
Abstract
This article concentrates on comparing the testimony of legislative experts with theoretical approaches to the statutory drafting. The aim is to map out their concepts of activity they are doing. The aim of the article is to present basic possible approaches to studying law-related processes, in particular the phase that takes place at government level, i.e. within the bureaucratic apparatus that the government, as a typical proposer of legisla- tive proposals, has. Therefore, the article combines empirical procedures (qualitative research to create a meth- odology for further empirical research) with a doctrinal approach to analyzing available literary knowledge.

\footnotetext{
* Tento článek je výsledkem badatelské činnosti podporované Grantovou agenturou České republiky, reg. č. GA17-14903S - „Metodologie empirického zjišt’ování využití interpretačních metod v tvorbě práva“. Označení „legislativec“ $v$ tomto textu používáme jako označení pracovní pozice. Chceme ale zdůraznit, že mezi našimi informanty byly samožrejmě také ženy, které tuto pozici zastávají stejně jako muži. Zůstáváme ovšem u toho obecného označení především proto, abychom neužívali zbytečných opisů slova, které v češtině nemá vhodný ženský tvar.

** Doc. JUDr. Mgr. Martin Škop, Ph.D., Katedra právní teorie, Právnická fakulta, Masarykova univerzita, Brno / Department of Legal Theory, Faculty of Law, Masaryk University, Brno, Czech Republic / E-mail: 11158@law.muni.cz / ORCID: 0000-0002-2727-8059

*** Mgr. Barbora Vacková, Ph.D., Katedra mediálních studií a žurnalistiky, Fakulta sociálních studií, Masarykova univerzita, Brno / Department of Media Studies and Journalism, Faculty of Social Studies, Masaryk University, Brno, Czech Republic / E-mail: bvackova@mail.muni.cz
} 


\section{Keywords}

Creation of Norms; Empirical Research; Statutory Drafting; Qualitative Research; Legislation; Language Interpretation.

\section{Úvod}

V roce 1917 si francouzský profesor občanského práva Henri Capitant povzdechl, že dílo, jakým byl občanský zákoník z roku 1804 (Code civil des Français), se již zřejmě nepodaří vytvořit - zejména vinou zákonodárce. ${ }^{1}$ Tvrdil, že umění tvořit zákony se propadá do zapomnění a schopnosti tvưrců nikdy nebyly na tak nízké úrovni. ${ }^{2}$ Podobně vytýkal - s ohledem na klesající úroveň jazyka legislativy - Friedrich Carl von Savigny tehdejším zákonodárcům, že jejich předpisy se v síle a razanci vyjadřování nemohou vyrovnat Constitutio Criminalis Carolina (Peinliche Halsgerichtsordnung Kaiser Karls V). ${ }^{3}$ Lze se - poněkud nadneseně řečeno - domnívat, že schopnosti tvořit právo byly vždy vystaveny určité skepsi starší generace, která neskrývala, a neskrývá, své rozčarování z aktuální úrovně legislativy a schopnosti zákony psát. Capitant se však ve svém textu, který se věnuje zejména vadám, které novelizace občanského zákoníku př́nesly, a jejich legislativními nedostatky, dotýká také otázky, zda je tvorba práva formální racionalizovanou činností, která má povahu rutiny, př́ípadně, zda se jedná o umění (l’art), resp. tvưrčí činnost. Tvorbu práva ${ }^{4}$ totiž lze skutečně na jedné straně vnímat jako umění, ${ }^{5}$ anebo na té druhé jako striktně formalizovanou činnost, ve které je minimalizován prostor pro kreativní postupy. ${ }^{6}$ Tato polarizace je do určité míry konstruktem, nebot' si nelze

1 CAPITANT, Henri. Comment on fait les lois aujourd'hui. Revue Politique\& Parlementaire, 1917, roč. 91, č. 269 , s. 305 .

2 Ibid., s. 307.

3 SAVIGNY, Friedrich Carl von. Vom Beruf unserer Zeit für Gesetzgebung und Rechtswissenschaft. Heidelberg: Mohr und Zimmer, 1814, s. 52.

4 Povšimněme si banální skutečnosti, že i v českém ustáleném pojmu „tvorba práva“ se vyskytuje slovo „tvorba“ a nikoli pouze „psani““ či „,vytvářenii“ nebo „právodárstvi““ dle vzoru „zákonodárstvi“.

5 Viz např. SVÁK, Ján a Peter KUKLIŠ. Teória a prax legislatívy. Bratislava: Bratislavská vysoká škola práva, 2009, s. 63 a násl.

6 Nezbytnost racionálního diskursu v parlamentním prostředí zmiňuje např. Jan Kysela, čímž mu samožrejmě nelze podsunout odmítání tvưrčího prvku. KYSELA, Jan. Zákonodárný proces v České republice. Právník, 2005, roč. 144, č. 6, s. 590. Není však důvod se domnívat, že pokud je racionální diskurs nezbytný v politickém prostředí parlamentních orgánů, pak by neměl - tím spíše - svůj význam i v prostředí administrativy, která vytváŕí návrhy právních předpisů a předkládá je př́slušným pravomocným orgánům ke schválení. Současně však racionalita procesu nevylučuje tvůrčí prvky. Jakýkoli proces v tvorbě práva má racionální jádro, které např́klad poměřuje vztah prostředků a účelů (viz dále), ale nelze vyloučit, že i v takto racionálním prostředí existuje dost prostoru pro kreativní činnost, která - v některých př́padech - může působit proti instrumentální racionalitě. Na př́kladu legislativy tak lze aplikovat střed mezi účelověracionálním jednáním a afektivním jednáním a (viz WEBER, Max. Metodologie, sociologie a politika. Praha: OIKOYMENH, 2009, s. 155). Max Weber racionalitu práva podmiňoval kumulativně logickon koherenci, úplností, deduktivním charakterem práva, jeho metodologickou specificností, axiologickou neutralitou a formální legitimitou. COUTU, Michel. Max Weber's Interpretive sociology of Law. London: Routledge, 2018, s. 87-89. 
představit, že by pracovníci legislativních odborů ministerstev postupovali zcela spontánně, bez ohledu na jakákoli pravidla a stejně tak je obtížné předpokládat, že by byli mechanickými stroji produkujícími, pomocí striktně formalizovaných postupů, výsledky požadované věcným zadáním. Přesto se ukazuje - jak v teoretické literatuře, tak ve výpovědích samotných legislativců - že tato polarizace provází jejich práci a pomáhá jejich činnost pochopit.

Tento článek se soustředí na porovnání výpovědí legislativních expertů (dále také jako legislativci či legislativní pracovníci), tj. zejména úředníků a úřednic pracujících na ministerstvech, jejichž pracovní náplní je vytvářet návrhy právních předpisů, s teoretickými př́stupy $\mathrm{k}$ tvorbě práva. Cílem je alespoň částečně zmapovat jejich pojetí jimi prováděné činnosti, která má vést ke vzniku právního předpisu. Zejména s tím ohledem, že tvorbu práva lze chápat jako tzv. anticipovanou interpretaci, ${ }^{7}$ což zcela jasně vystihuje vzájemnou propojenost tvorby a aplikace (interpretace) práva. Text proto vychází zejména z analýzy zjištění získaných při hloubkových rozhovorech se zaměstnanci ministerstev, kteří působí v legislativních odborech, a jejichž náplní práce je př́íprava právních předpisů. Na tvorbě práva (na všech úrovních) se nepochybně podílejí i další lidé, nejen legislativní experti a nelze říci, že by jejich role byla marginální. Vzhledem k tomu, že legislativní experti však přichází k psaní návrhů nejčastěji a systematicky, a také u nich lze předpokládat právnické vzdělání, tedy alespoň elementární teoretickou znalost prríslušné metodologie, byli do zkoumání zahrnuti výlučně. Nelze také pominout, že byrokratické fáze procesu tvorby práva - ve kterých legislativní experti nejčastěji působí - nepředstavují pouze tvorbu jako takovou, ale zahrnují i př́pravu politik, tj. nastolování témat, která mají být řešena právními předpisy, případně zahrnují i vyjadřování $\mathrm{k}$ jiným návrhům a jejich připomínkování. Přestože se ne nutně podílí na přímé tvorbě právních předpisů, mají legislativní experti výrazný vliv na tvorbu práva. ${ }^{8}$

Tyto empiricky získané poznatky jsou dány do souvislosti s teoretickou literaturou. Článek proto kombinuje empirické postupy (kvalitativní šetření s cílem vytvořit metodologii pro další empirická zjišt'ovánî) s doktrinálním př́stupem zaměřeným na analýzu dostupných literárních poznatků, tedy s poznatky plynoucími z odborné literatury. To navzdory

7 WINTR, Jan a Jan KYSELA. In: BOHÁČ, Radim et al. Legislativní proces (teorie a praxe). Praha: Tiskárna Ministerstva vnitra, 2011, s. 45. Podobně o vztahu interpretace a tvorby práva také viz WINTR, Jan. Metody a zásady interpretace práva. Praha: Auditorium, 2013, s. 49.

8 ROBINSON, Chester A. The Bureaucracy and the Legislative Process. A Case Study of the Health Care Financing Administration. Lanham: University Press of America, 1991, s. 1. 
tomu, že podle některých autorů právní teorie tvorbu práva značně zanedbávala, ${ }^{9}$ včetně podcenění analýzy jejích funkcí a vztahu $\mathrm{k}$ rozhodovací praxi. ${ }^{10}$ To může být patrné i $\mathrm{v}$ tom, že z pohledu technik interpretace a technik tvorby práva chybí odpovídající interpretačni dialog mezi jednotlivými právními aktéry a soudy na straně jedné a parlamentem na straně druhé. Setkáváme se spíše s direktivními zásahy, což je pochopitelně v souladu s pravomocí jednotlivých institucí. Méně se lze setkat s vysvětlením a skutečně důkladným rozborem soudní interpretační praxe parlamentem ${ }^{11}$ a legislativní činnosti soudy (zejména s důrazem na legislativní praxi a tzv. legislativní historii). Není patrné, že by legislativní experti systematicky identifikovali interpretační praxi (byt' jim není neznámá) a přizpo̊sobovali jí pravidla tvorby. ${ }^{12}$ Rovněž není patrné, že by orgány autoritativně aplikující právo systematicky formovaly interpretační metodologii. ${ }^{13}$ Přitom vzájemná reflexe praxe, tedy interpretační dialog, napomáhá zlepšovat legislativní výstupy a celkové fungování práva. Napomáhá legitimní evoluci práva, ${ }^{14}$ ale také precizaci obsahu právních předpisů a zretetelnému ustálení odpovídající interpretační metodologie. Cílem článku není podat vyčerpávající, či reprezentativní pohled na zkušenosti legislativců, ale spíše předložit základní možné př́istupy ke studiu procesů spjatých s tvorbou práva,

9 WINTGENS, Luc J. Legislation as an Object of Study of Legal Theory: Legisprudence. In: WINTGENS, Luc J. (ed.). Legisprudence: A New Theoretical Approach to Legislation. Oxford: Hart Publishing, 2002, s. 9. Podobně se vyjadřují i Abbe R. Gluck a Lisa Schultz Bressman, viz GLUCK, Abbe R. a Lisa SCHULTZ BRESSMAN. Statutory Interpretation from the Inside - An Empirical Study of Congressional Drafting, Delegation, and the Cannons: Part I. Stanford Law Review, 2013, roč. 65, č. 5, s. 907 . V českém prostředí však tvorba práva má relevantní teoretickou oporu viz např. KNAPP, Viktor. Teoretické problémy tvorby československébo práva. Praha: Academia, 1983; KNAPP, Viktor. Tvorba práva a její současné problémy. Praha: Linde, 1998; BOHÁČ, Radim et al. Legislativní proces (teorie a praxe). Praha: Tiskárna Ministerstva vnitra, 2011; ŠÍN, Zbyněk. Tvorba práva: pravidla, metodika, technika. 2. vyd. Praha: C. H. Beck, 2009; GERLOCH, Aleš et al. Teorie a praxe tvorby práva. Praha: ASPI, 2008. Soustředí se však především na parlamentní část, případně na techniku tvorby. Chybí však relevantní propojení mezi empirickými zjištěními a teoretickými závěry, byt' těmto publikacím nelze upř́it výrazný praktický rozměr.

10 LANDIS, James McCauley. Statutes and the Sources of Law. Harvard Journal on Legislation, 1965, roč. 2, č. 1 , s. 23.

11 Byt' je to nezbytná součást tvorby práva - tzv. technickoorganizačních principů (aplikační informace). Viz KNAPP, Viktor. Teoretické problémy tvorby československébo práva. Praha: Academia, 1983, s. 113-114.

12 Byt' ke změně legislativních pravidel dochází (viz např. ŠKOP, Martin. Legislativní zvyklosti. Právník, 2018, roč. 157, č. 9, s. 724), není veřejně přístupná žádná diskuse, která tomu předchází, př́ípadně relevantní analýza aplikační a interpretační praxe.

13 Obvyklé je, že se soudy odvolávají na obvyklé interpretační metody [viz např. nález ze dne 2. 7. 1997, sp. zn. Pl. ÚS 2/97 (N 91/8 SbNU 325; 186/1997 Sb.); nález ze dne 12. 3. 2008, sp. zn. Pl. ÚS 83/06 (N 55/48 SbNU 629; 116/2008 Sb.), bod 186; nález ze dne 27. 11. 2012, sp. zn. Pl. ÚS 1/12 (N 195/67 SbNU 333; 437/2012 Sb.), bod 339]. To se však nejeví jako dostatečné, protože se jedná pouze o obecný odkaz, aniž by soud tyto metody blíže identifikoval a zejména zohlednil prrípadný vývoj s ohledem na (případný) posun v procesu tvorby práva a vzal v úvahu, zda normotvưrce dodržuje stále stejné metody psaní normativního textu. Takovéto obecné závěry pak interpretačnímu dialogu sice napomáhají, nebot’ lze určit, co Ústavní soud nepovažuje za srozumitelné ani po použití „obvyklých metod“, avšak nestačí to pro určení, co je príkladem dobré praxe.

14 CHRISTIANSEN, Matthew R. a William N. ESKRIDGE jr. Congressional Overrides of Supreme Court Statutory Interpretation Decisions, 1967-2011. Texas Law Review, 2014, roč. 92, č. 6, s. 1322. 
zejména s fází, která probíhá na vládní úrovni, tj. v rámci byrokratického aparátu, kterým vláda, jako typický předkladatel návrhů právních předpisů, disponuje. V článku se rovněž čtenář nedozví, co to skutečně znamená být legislativcem. Pro to nejsou získaná data reprezentativní. Jde spíše o to poukázat, jaké aspekty se jeví pro samotné legislativní experty a expertky významné při popisu jejich činnosti. Zcela nepokrytě sami aktéři směřují spíše k tomu, chápat svou činnost jako řemeslo, které s sebou nese něco navíc, což může být onen výsledek nastíněného střetu formalizovaného a tvưrčího přístupu.

\section{Význam analýzy chování normotvůrce}

Jaký význam však může mít analýza byrokratických procesů, které spočívají v kompozici návrhu normativního textu? Normativní text je specifickým komunikačním prostředkem, kterým jsou sdělovány žádoucí zpo̊soby lidského chování. To také znamená, že jsou jím sdělovány i způsoby, které nejsou žádoucí, resp. ty, které jsou prímo sankcionovány. Je proto nezbytné, aby mezi tvůrcem a př́jemcem (adresátem) došlo k porozumění. Tvưrce adresátovi sděluje, co považuje za žádoucí model chování, jaká pravidla má adresát dodržovat, a jaké chování bude postihováno. Pro zjednodušení tohoto komunikačního procesu a pro větší srozumitelnost slouží celá řada legislativních metod nebo technik, které tvůrci usnadňují vytváření textu a adresátovi jeho interpretaci. Přestože tyto techniky či metody nejsou stanoveny závazně, jejich pragmatickou funkcí je zvýšit úspěšnost komunikace a sdělit adresátovi ty významy, které tvůrce zamýšlí. V tom se jeví jako žádoucí nejen stanovit, jaké př́stupy by měly být adekvátní, ${ }^{15}$ a které nejvíce následují racionální model tvorby práva, ale také postupy, které jsou v praxi skutečně využívány. Abbe R. Gluck a Lisa Schultz Bressman ${ }^{16}$ ve svém kvantitativním šetření znalosti interpretačních technik legislativci zjistily, že ti si nejsou často vědomi toho, že by využívali nějaké specifické doktríny spadající do oblasti právní teorie nebo metodologie. Současně však uvedly, že tito experti potvrdili, že legislativní procesy a postupy jsou na základě těchto doktrín a metod vytvořeny. ${ }^{17}$ To podporuje pojetí legislativy jako rutinizované činnosti. ${ }^{18}$ Legislativa může probíhat bez hlubokých znalostí právní

15 K těmto postupům viz např. KNAPP, Viktor. Teoretické problémy tvorby československého práva. Praha: Academia, 1983; KNĚŽÍNEK, Jan, Petr MLSNA a Josef VEDRAL. Přprava návrbui právních prédpisü: praktická pomuicka pro legislativce. Praha: Úřad vlády České republiky, 2010; ŠÍN, Zbyněk. Tvorba práva: pravidla, metodika, technika. 2. vyd. Praha: C. H. Beck, 2009.

16 GLUCK, Abbe R. a Lisa SCHULTZ BRESSMAN. Statutory Interpretation from the Inside - An Empirical Study of Congressional Drafting, Delegation, and the Cannons: Part I. Stanford Law Review, 2013, roč. 65, č. 5, s. 901-1026. GLUCK, Abbe R. a Lisa SCHULTZ BRESSMAN. Statutory Interpretation from the Inside - An Empirical Study of Congressional Drafting, Delegation, and the Cannons: Part II. Stanford Law Review, 2014, roč. 66, č. 4, s. 725-802.

17 GLUCK, Abbe R. a Lisa SCHULTZ BRESSMAN. Statutory Interpretation from the Inside - An Empirical Study of Congressional Drafting, Delegation, and the Cannons: Part I. Stanford Law Review, 2013, roč. 65 , č. 5, s. 907.

18 To neznamená, že se jedná o nějakou podřadnou činnost, ale mimo jiné o činnost, která se učí nápodobou a pomáhá v organizované činnosti. 
doktríny, nebot' ty poskytují podporu pouze při explanaci či legitimizaci jednotlivých kroků či výstupů. ${ }^{19}$ Nemůže však probíhat bez rutiny: bez ustálené koordinované činnosti jednotlivých aktérů v legislativním poli, při které se znalosti a dovednosti předávají nápodobou, aniž by musely projít epistemickou reflexí. Na druhou stranu, jak poznamenává Robert K. Merton, přilišný důraz na rutiny a dodržování (byt’ efektivních) pravidel, může vést k tomu, že činnost byrokratického aparátu se odtrhne od cílů, které má sledovat. ${ }^{20} \mathrm{~V}$ tomto ohledu se tvůrčí prvek v procesu tvorby práva může stát tím, co prŕlišnou rutinu napomůže modifikovat směrem $\mathrm{k}$ určeným cílům.

V současnosti čelíme nárůstu počtu právních norem ${ }^{21}$ a s tím spojené potenciální desystemizaci právního řádu, jejíž jednou z př́čin může být i klesající úroveň přípravy legislativního návrhu. ${ }^{22}$ Transformace obecného společenského diskursu, hodnot a společenských očekávání do podoby právního textu ${ }^{23}$ není snadná a v reálných podmínkách se bude obtížně prribližovat teoretickému ideálu. Normy, při jejichž prŕpravě nebyly dodrženy všechny žádoucí postupy, mohou dokonce více problémů vyvolávat než řešit. ${ }^{24}$ To se pochopitelně týká i normativního textu, jehož nedostatky mohou právní praxi doslova paralyzovat. Z tohoto pohledu se stává velmi důležitou identifikace procesů, které vedou k vytvoření návrhu právního předpisu. Nejde o to, že by tato zjištění měla preskriptivní povahu. Měla by napomoci identifikovat základní problematická místa $\mathrm{v}$ legislativním procesu. Rovněž lze říci, že tvorba práva je nákladnou činností, která také další náklady (minimálně na aplikaci) vyžaduje. Je proto žádoucí, aby její výsledky byly co nejvíce využitelné. ${ }^{25}$

Krom významu vědeckého (samotné poznání procesu tvorby), komunikačního (sdělování mimoprávního obsahu) a ekonomického (náklady), je analýza postupů spojených s tvorbou práva významná i pro interpretaci práva. Objektivizovaná podoba legislativních prací,

19 Viz např. PECZENIK, Alexander. A Theory of Legal Doctrine. Ratio Juris, 2001, roč. 14, č. 1, s. 76.

20 MERTON, Robert K. Social Theory and Social Structure. Enlarged ed. New York: The Free Press, 1968, s. 253.

$21 \mathrm{~K}$ situaci v České republice, případně i ke srovnání s ostatními zeměmi střední Evropy, viz CVRČEK, František a František NOVÁK. Legislativa: teoretická východiska a problémy. Plzeň: Vydavatelství a nakladatelství Aleš Čeněk, 2017.

22 WINTGENS, Luc J. The Rational Legislator Revisited. Bounded Rationality and Legisprudence. In: WINTGENS, Luc J. a Daniel A. OLIVER-LALANA (eds.). The rationality and justification of legislation: essays in legisprudence. New York: Springer, 2013, s. 4. To se mimo jiné potvrzuje i ve výpovědích legislativních expertů. Podle jejich zkušeností jsou věcné záměry zpracovány setrvale nedostatečně.

23 CYRUL, Wojciech. Lawmaking: Between Discourse and Legal Text. In: WINTGENS, Luc a Philippe THION (eds.). Legislation in context: essays in legisprudence. Burlington: Ashgate, 2007, s. 50.

24 Nedostatečná př́prava může vést například k nesrozumitelnosti textu. Byt’ se jedná o daňové právo, kde lze předpokládat důraz na přesnost a sdělnost textu, nelze přehlédnout, že v nálezu ze dne 6. 6. 2013, sp. zn. II. ÚS 2429/12 (N 101/69 SbNU 675) Ústavní soud (mimo jiné) pracuje s imperativy dostatečné určitosti. Lze doplnit, že bez dostatečné přípravy a bez dodržení náležitostí tvorby práva nelze provázanost předpisů a vnitřní bezrozpornost u tak složité oblasti jako je daňové právo dosáhnout.

25 BIELSKA-BRODZIAK, Agnieszka. Śladami prawodawcy faktycznego: materiaty legislacyjne jako narz̧edzie wyktadni prawa. Warszawa: Wolters Kluwer Polska, 2017, s. 28. 
resp. legislativní historie (či také travaux préparatoires) ${ }^{26}$ se používají jako jedny ze zdrojů tzv. intencionalistického výkladu, který směřuje k identifikaci záměru (subjektivního úmyslu) zákonodárce. ${ }^{27}$ Jeho použitím se lze např́klad dobrat zamýšlených ekonomických, politických nebo sociálních cílů, které v právním textu nemohou být vyjádřeny. ${ }^{28}$ Př̀ tom je možné použít vše, co umožní nahlédnout do duše qákonodárce, ${ }^{29}$ což nepochybně mohou být i př́pravné práce. Identifikace těchto mimoprávních prvků může napomoci interpretaci práva a zjištění relevantního obsahu normativního textu, prípadně správně aplikovat právní normu na konkrétní skutečnost. ${ }^{30} \mathrm{Na}$ tom nic nemění ani skutečnost, že ideál racionálního normotvůrce, se kterým pracuje interpretační praxe, se liší od skutečnosti, kdy reálný normotvưrce nezbytně někdy podřídí výsledek kompromisu nebo vyjednávání a „politickým obchodům“ na úkor legislativní kvality. ${ }^{31}$ Tento ideál má nepochybně unifikační vliv a pomáhá sjednocovat interpretační praxi podř́zením racionálním kritériím.

V této souvislosti je tak nutné akceptovat byrokratický model působení státní správy a jeho podíl na formování právních předpisů, který není zcela oproštěn od politických tlaků, ale má nástroje (zejména administrativní a expertní povahy - bez ohledu na to, zda se jedná o experty legislativní, nebo experty na věcný obsah př́islušné právní úpravy, či na reálnou oblast, která je regulována), které tyto tlaky mohou zmenšit. Působení byrokracie $\mathrm{v}$ procesu tvorby práva má vliv na její výsledky (právní předpisy), zejména předpokládaným působením na expertní úrovni. ${ }^{32}$ Potenciál eliminovat politické tlaky se však může obrátit a experti mohou působení těchto tlaků prohlubovat: ${ }^{33}$ některé parciální zájmy se může podařit eliminovat, naopak jiné - opět díky specializovaným a hlubokým znalostem - prosadit. Experti však vždy budou mít v procesu tvorby práva (doufejme) zásadní roli. ${ }^{34}$ Od expertů, a opět bez ohledu na sféru jejich působení, je vhodné

26 Viz např. JESTAZ, Philippe. Les sources du droit: le déplacement d'un pôle à un autre. Revue générale de droit, 1996, roč. 27. č. 1, s. 15.

27 SOBEK, Tomáš. Argumenty teorie práva. Praha: Ústav státu a práva, 2008, s. 218.

28 SOBEK, Tomáš. Právní myšleni - kritika moralismu. Praha: Ústav státu a práva, 2011, s. 242.

29 WINDSCHEID, Bernhard. Lebrbuch des Pandektenrechts. Svazeek 1. Düsseldorf: Verlagshandlung von Julius Buddeus, 1862, s. 49.

30 SOBEK, Tomáš. Právni myšlení - kritika moralismu. Praha: Ústav státu a práva, 2011, s. 242.

31 NOURSE, Victoria F. a Jane S. SCHACTER. The Politics of Legislative Drafting: A Congressional Case Study. New York University Law Review, 2002, roč. 77, č. 3, s. 614.

32 NICHOLSON-CROTTY, Jill a Susan M. MILLER. Bureaucratic Effectiveness and Influence in the Legislature. Journal of Public Administration Research and Theory, 2011, roč. 22, č. 2, s. 351.

33 SCHULZE-FILEITZ, Helmuth. Paths Towards Better Legislation, Detours and Dead-Ends. An Appraisal of Consultation with Independent Experts, Justifications for Legislation, Impact Assessments and Controls of Efficacy. In: MEßERSCHMIDT, Klaus a Daniel A. OLIVER-LALANA (eds.). Rational Lawmaking under Review,. Heidelberg: Springer, 2016, s. 48.

34 GLUCK, Abbe R. a Lisa SCHULTZ BRESSMAN. Statutory Interpretation from the Inside - An Empirical Study of Congressional Drafting, Delegation, and the Cannons: Part I. Stanford Law Review, 2013, roč. 65 , č. 5 , s. 916. 
odlišovat tzv. lobbisty, tedy osoby se specifickým zájmem na obsahu právního předpisu. Jejich odlišení od expertů není snadné a v mnoha př́padech se tyto kategorie mohou překrývat. Tzv. lobbisty bychom však měli chápat jako osoby mající parciální zájem na obsahu právní regulace či tento zájem zastupující, zatímco expert primárně operuje se svým poznáním a své zájmy potlačuje. Byt' mohou lobbisté působit pozitivně, nebot' jsou nejblí̌e zkušenostem subjektů, na které bude regulace dopadat, ${ }^{35}$ nelze podcenit ani jejich potenciální tendenční zásahy, které mohou být užitečné jen úzké skupině adresátů.

Vliv byrokracie na tvorbu práva je plně v souladu s obvyklým pojetím byrokratizované moci. Podle Daniela Carpentera se moc, v tomto smyslu jakákoli, projevuje ve třech rovinách: ovládá jednání lidí (directive power), definuje a určuje, co je problém a co je nezbytné řešit (gatekeeping power) a určuje obsah a formu lidského poznání (conceptual power). ${ }^{36}$ Tyto složky se postupně přesouvají na byrokracii, která disponuje dostatečným aparátem a expertními znalostmi, aby toto určování zvládala. Proto lze konstatovat, že tyto tři roviny působení moci se projevují nejen $\mathrm{v}$ právní oblasti obecně, ale také $\mathrm{v}$ oblasti tvorby práva. Formování legislativních znalostí, definování problému, který je nezbytné řešit, a direktivní stanovení způsobu, jakým řešení bude probíhat, včetně systematického zvládnutí procesu, jsou prvky, které tvorbu práva provázejí, a které je nezbytné pro popis tvorby práva znát. Jsou to nezbytné součásti analýzy procesů vzniku práva. ${ }^{37}$ Podle Chestera A. Robinsona je proto nezbytné porozumět byrokratickým fázím procesu tvorby práva, protože $\mathrm{v}$ demokratické společnosti je nezbytné vědět, jak administrativa pracuje, jakým způsobem přijímá rozhodnutí, jakým podléhá vlivům a jakým způsobem formuluje své výstupy ${ }^{38} \mathrm{~S}$ tím, že byt' předpokládáme, že byrokracie je technicky efektivní způsob řešení problémů, který je schopen působit bez ohledu na vnější vlivy, ${ }^{39}$ ve skutečnosti není vůči těmto vlivům zcela imunní.

\section{Dílčí předpoklady zkoumání}

Zkoumání využití metod interpretace v procesu tvorby práva, tj. postupů, které legislativní pracovník při své činnosti zvažuje či skutečně používá, nezbytně musí akceptovat doktrinální prýstup. Přístup, který se soustředí na akademické, či teoretické, přístupy ke zkoumání (interpretaci) pramenů práva. Obecně v právní vědě převažuje důraz

35 NOURSE, Victoria F. a Jane S. SCHACTER. The Politics of Legislative Drafting: A Congressional Case Study. New York University Law Review, 2002, roč. 77, č. 3, s. 611.

36 CARPENTER, Daniel. Reputation and Power. Organizational Image and Pharmaceutical Regulation of the FDA. Princeton: Princeton University Press, 2010, s. 15.

37 KYSELA, Jan. In: GERLOCH, Aleš et al. Teorie a praxe tvorby práva. Praha: ASPI, 2008, s. 21.

38 ROBINSON, Chester A. The Bureaucracy and the Legislative Process. A Case Study of the Health Care Financing Administration. Lanham: University Press of America, 1991, s. 15.

39 MERTON, Robert K. Social Theory and Social Structure. Enlarged ed. New York: The Free Press, 1968, s. 250 . 
na preskriptivní teorie, ${ }^{40}$ které sdělují, jak se má postupovat, tedy v našem př́ípadě, jakým způsobem se má správně tvořit normativní text, a to zejména při využití postupů, které se mají používat v interpretaci, aby byla správná. Tento přístup je mnohem bližší zmíněnému doktrinálnímu přístupu. Deskriptivní teorie ${ }^{41}$ oproti tomu kladou důraz na to, jak reálné subjekty skutečně tvoří normativní text, jaké si formují symbolické prostředí, ve kterém svou činnost provádí, případně jak normativní text skutečně interpretují. Využívají při tom nejčastěji empirické prŕstupy zkoumání sociální reality a identifikují postupy, které se př́i tvorbě práva využívají. Při zkoumání tvorby práva je nezbytné spojit oba př́stupy a postupovat jak doktrinálně (preskriptivní přístup), tak empiricky (deskriptivní př́stup). Je nezbytné doktrinálně identifikovat právní prostředí, pravidla a jejich význam, které podávají normativní vzorec tvorby práva, a kombinovat jej s př́stupy empirickými, tedy identifikací toho, jak legislativní pracovníci skutečně tyto postupy využívají, př́padně, kde a proč volí postupy jiné. Tato zjištění lze porovnat a dospět k přesnějšímu obrazu byrokratických částí procesu tvorby práva.

Obvyklé pojetí doktríny, či doktrinálního přístupu v právní vědě, směřuje k syntetickému vnímání pravidel, principů, zvyklostí a hodnot, pomocí kterého se vysvětlují či ospravedlňují určité části práva jako součást právního rádu. ${ }^{42}$ Proto se doktrinální př́stup stává relevantní pro zkoumání právních pravidel (objektivního práva) a právních pojmů. V tomto př́padě je relevantní jak pro zjišt'ování pravidel interpretace či pro zjišt’ování pravidel, která regulují tvorbu práva. Tento př́ístup je však často intuitivní a probíhá bez potřeby jej reflektovat či př́mo verbalizovat. To jej samo o sobě nijak nediskvalifikuje, problematizuje to však jeho předávání, případně srozumitelnost mimo úzkou skupinu expertů. Je také velmi obtížně takto dosažená zjištění verifikovat a dodržet tak požadavky transparentnosti jakéhokoli vědeckého bádání. Tím se také nijak nesnižuje cíl tohoto přístupu, tedy odhalit pravidla, která vyplývají z autoritativních pramenů práva, a uspořádat je do uceleného a racionálního sytému, který je koherentní v rámci určité teorie. ${ }^{43}$ Je to př́stup, který popisuje právo ze sebe samého a hledá v něm správná pravidla, tj. pravidla, která jsou v tomto případě - při zohlednění celku - přítomná.

40 ESKRIDGE jr., William N., Philipp P. FRICKEY a Elizabeth GARRETT. Legislation and Statutory Interpretation. New York: Foundation Press, 2006, s. 219. Označení preskriptivní není obecně přijímáno vzhledem ke konotacím, které to může mít a které vedou ke ztotožnění právní vědy nebo obecně práva s právní politikou. Např. Hans Kelsen trval na odlišení práva a politiky v tom smyslu, že právo je technickým nástrojem viz KELSEN, Hans. The Law of the United Nations. A Citical Analysis of Its Fundamental Problems. London: Stevens and Sons, 1951, s. xiii.

41 Ibid., s. 220.

42 HUTCHINSON, Terry a Nigel DUNCAN. Defining and Describing What We Do: Doctrinal Legal Research. Deakin Law Review, 2012, roč. 17, č. 1, s 84.

43 MCCONVILLE, Michael a Wing Hong CHUI. Research methods for law. 2. vyd. Edinburgh: Edinburgh University Press, 2017, s. 1. 


\section{Tvorba práva jako racionální činnost a jako umění}

Již výše jsme identifikovali povzdech, kterým Henri Capitant či Friedrich Carl von Savigny počastovali zhoršující se úroveň legislativního procesu, konkrétně umění tvořit (psát) zákony. Samozřejmě zde nejde o proces, který se odehrává v ústavou definovaných legislativních tělesech (v současnosti typicky v parlamentech). Parlamenty spíše slouží $\mathrm{k}$ tomu, aby se text stal všeobecně závazným, v tomto smyslu platným normativním textem. ${ }^{44}$ Obvykle v nich však nedochází prímo k psaní návrhu (byt' existují četné výjimky). ${ }^{45}$ Jedná se o skutečné psaní, kompozici normativního textu, na kterém se podílí celá řada aktérů: možno říci až komplex aktérů, což - paradoxně - může vést k vzrůstající nejasnosti textu, ${ }^{46}$ nebot' každý z aktérů do textu může promítat jiné myšlenky, může části jinak chápat, př́padně text může spojovat s jinými účely. To se neděje jen na úrovni vzniku návrhů, ale při samotném procesu schvalování. Nelze pominout, že v kolektivním orgánu, kterým parlamenty nepochybně jsou, nemusí mít každý jednotlivý člen shodný záměr jako jiní, ${ }^{47}$ dokonce pravděpodobnost, že bude uniformní, je mizivá. ${ }^{48}$ Navíc, v reálném prostředí se na tvorbě i samotném schvalování podílí celá řada úředníků, kteři mají na věc vlastní názor.

Podobný povzdech jako Capitant publikoval o téměř osmdesát let později i další francouzský právník Guy Braibant, který také konstatoval, že se umění psát zákony zhoršilo. ${ }^{49}$ Tvrdil, že prŕliš mnoho úředníků, či státních zaměstnanců, píše právní předpisy, které vyjadřují něco jiného, než mají, jejich tvůrci netuší nic o používaných ustálených pojmech či legislativních technikách, př́padně nemají ponětí o tom, že co pracně vymýšlejí, již existuje. To je pro Braibanta, mimo jiné, i příčina toho, že v právu se již laik nemá šanci vyznat a je prrístupné pouze specialistům. Domníváme se, že i dnes, o dalších dvacet pět let později, bychom žehrání na úroveň legislativní práce našli také dost.

44 MARCISZ, Paweł. Koncepcja tworzenia prawa prz̨ez Trybunat sprawiedliwości Unï Europejskiej. Warszawa: Lex, 2015, s. 25 .

45 Někdy se lze setkat s názorem (ne zcela nemístným), že úroveň legislativních návrhů vznikajících přímo na půdě parlamentů, nebo dokonce přímo na schůzi, není príliš vysoká - viz NOURSE, Victoria F. a Jane S. SCHACTER. The Politics of Legislative Drafting: A Congressional Case Study. New York University Law Review, 2002, roč. 77, č. 3, s. 592. V tomto směru je možné dokonce uvést, že př́iklad ze Spojených států amerických, kde je expertní aparát Kongresu velmi rozvinutý, může v evropských podmínkách nabýt ještě více negativní podoby - viz KYSELA, Jan. Ústava mezi právem a politikou. Úvod do ústavni teorie. Praha: Leges, 2014, s. 295-296.

46 BRAIBANT, Guy. Qui fail la loi? Pouvoirs, revue française d'études constitutionnelles et politiques, 1993, č. 64 Le Parlement, s. 44.

47 JELLUM, Linda D. a David HRICIK. Modern statutory interpretation: problems, theories, and lanyering strategies. Durham: Carolina Academic Press, 2009, s. 48.

48 RADIN, Max. Statutory Interpretation. Harvard Law Review, 1930, roč. 43, č. 6, s. 863.

49 BRAIBANT, Guy. Qui fail la loi? Pouvoirs, revue française d'études constitutionnelles et politiques, 1993, č. 64 Le Parlement, s. 45. 
Tvorbu práva, tedy konkrétně vyjadřování normativů v textu, který má ambici být normativním textem, lze považovat jak za činnost racionální, tak za činnost kreativní. Nejčastěji budou tyto dva aspekty legislativy skutečně spojeny. Racionalita tvưrce spočívá především v jeho záměrech a normativních představách, zatímco činnost, ve které nezbytně pracuje se slovy a vyjadřuje proto právní normy formou obecného (či právního) jazyka, spíše kreativní. Racionální tak je nepochybně vztah mezi účelem regulace a zvolenými legislativními prostředky, nebo také diskurs, a zejména společenskopolitický kontext, ve kterém se normotvưrce pohybuje. ${ }^{50}$ Jaroslav Kallab - při popisu politiky chápal tvưrčí činnost jako takovou, která nespočívá pouze v používání pravidel, technik nebo metod na daný případ, tedy prostou, př́padně mechanickou aplikaci, ale jako činnost, která je spojena s individuálním úkonem, v němž se projevuje individualita jednajícího, jakož i individualita př́padu. ${ }^{51}$ Podle Johna Stuarta Milla slouží umění ke hledání cílů, k čemuž mu prostředky poskytuje věda - avšak umění je pak opět schopno z vědeckých poznatků zformovat pravidlo či předpis. ${ }^{52}$

Toto pojetí je použitelné i na tvorbu práva. Ani tato kreativita však nemá tendenci narušit předpoklad racionální tvorby práva v tom smyslu, že normotvůrci, tj. subjektu disponujícímu v konkrétním ústavním systému legislativní pravomocí, je prrisuzována schopnost postupovat racionálně a formovat racionálně své záměry. Tato jeho racionalita se přenáší i na tzv. empirického tvưrce či na byrokratický aparát tvořící návrhy právních předpisů. Tímto řetězem je legitimizován i výsledek - normativní text, nebot’ předpokladem je, že nedošlo k přetržení řetězu racionality. To odpovídá konceptu Maxe Webera, ve kterém právě systém záměrně vytvořených racionálních pravidel je jak zdrojem legitimity, tak základem závaznosti. ${ }^{53}$ Je však variabilní, jak velký důraz je kladen na racionální aspekt legislativní činnosti, př́padně jak velký význam a jaké meze má kreativní složka této činnosti.

Dominique Rémy považuje tvorbu normativního textu za stejně tvưrčí jako urbanistickou praxi. ${ }^{54} \mathrm{I} \mathrm{v}$ tomto případě tvưrčí činnost spočívá v kombinaci možných (reálných a racionálních) postupů v individualizovaných př́padech a vytváření celku, který je sice determinován, ale jeho výsledná podoba není kauzálně závislá pouze na těchto determinantech. Navíc, tvrdí Rémy, je nutné omezit př́lišnou tendenci soudů (či jiných autoritativně aplikujících subjektů) promítat do normativního textu své představy a vytvářet

50 WRÓBLEWSKI, Jerzy. Teoria racjonalnego tworzenia prawa. Wrocław: Wydawnictwo Polskiej akademii nauk 1985 , s. 11.

51 KALLAB, Jaroslav. Politika vědou a umèním. Základy teoretické politiky. Praha: Snaha, 1914, s. 15.

52 MILL, John Stuart. Collected Works of John Stuart Mill. Volume VIII. A System of Logic Ratiocinative and Inductive. Toronto: University of Toronto Press, 1974, s. 944-945.

53 WEBER, Max. Economy and Society. An outline of Interpretaive Sociology. Berkeley: University of California Press, 1978, s. 954.

54 RÉMY, Dominique. Légistique: L’art de faire les lois. Paris: Romillat, 1994, s. 15. 
své vlastní zákony, či obecnou tendenci právníků vyjednávat o obsahu zákonů. ${ }^{55} \mathrm{~S}$ tímto pojetím je tak skutečně propojena silná snaha oddělit zákonodárnou moc od moci výkonné a soudní a svěřit autoritativní tvorbu práva pouze do rukou parlamentů. Byt' s vědomím, že výslednou interpretaci lze ovlivnit pouze omezeně. Možné chápání legislativy jako tvůrčí činnosti také může znamenat, že snadněji půjde dosáhnout srozumitelnosti i pro různé zájmové skupiny. Tvůrce (skutečný pisatel) by se tak při tvorbě měl vyhnout svodům mechanické činnosti setrvávající plně v jednom specializovaném odvětví, a měl by hledat řešení přijatelné pro různé aktéry, př́padně řešení, které nese významy nejen v rovině právní, ale také v rovině pragmatické, či morální. ${ }^{56}$ Nejasná však stále zůstává povaha činnosti, která k těmto závěrům vede - je tvưrčí (kreativnî) nebo formální (mechanická)? Vzhledem k výše uvedené literatuře by právě tohle měl být doklad skutečné tvưrčí činnosti - resp. tvưrčí činnost by měla být zárukou toho, že normativní text bude srozumitelný i pro další subjekty, než pouze pro odborníky.

To však neznamená, že bychom vyloučili racionální pojetí tvorby práva. Jeden z př́stupů $\mathrm{k}$ tvorbě práva ji chápe jako převážně racionální proces, ve smyslu přísně formálním, ve kterém pro kreativitu zbývá jen velmi malé místo. Jerzy Wróblewski předpokládal, že tvorba práva je činností, která by měla být racionální, ${ }^{57}$ například ve smyslu vztahu prostředků a účelů. Tvoření návrhu normativního textu lze pak chápat jako rutinu, tedy opakované a šablonovité chování, které se při změně podmínek také mění (v opačném př́padě by se jednalo o jednání podle organizačních pravidel ${ }^{58}$, ve které vedle racionálního prvku převládá prvek dovednostní. Nezapomínejme také, že tvůrce normativního textu je odpovědný za racionalitu legislativy (návrhu zákona) a musí jednat v souladu se sociálním kontextem. ${ }^{59}$ To navíc v tom kontextu, že je racionální, aby výsledek legislativní činnosti byl srozumitelný, nebot’ interpret předpokládá, že tvorba práva je racionální. ${ }^{60}$

Na výše zmíněného Jerzyho Wróblewského navazuje i Viktor Knapp. I pro něj je tvorba práva plánovaným a cílevědomým procesem, který je těsně spojen s činností státní moci. ${ }^{61} \mathrm{Je}$ si však vědom $\mathrm{i}$ toho, že proces tvorby práva nelze redukovat pouze na činnosti

55 RÉMY, Dominique. Légistique: L'art de faire les lois. Paris: Romillat, 1994, s. 15.

56 CYRUL, Wojciech. Lawmaking: Between Discourse and Legal Text. In: WINTGENS, Luc a Philippe THION (eds.). Legislation in context: essays in legisprudence. Burlington: Ashgate, 2007, s. 51.

57 WRÓBLEWSKI, Jerzy. Teoria racjonalnego tworzenia prawa. Wrocław: Wydawnictwo Polskiej akademii nauk, 1985 , s. 8.

58 WINTER, Sydney. Economic "Natural Selection" and the Theory of the Firm. Yale Economic Essays, 1964, roč. 4, č. 1, s. 264, pozn. 2.

59 WINTGENS, Luc J. The Rational Legislator Revisited. Bounded Rationality and Legisprudence. In: WINTGENS, Luc J. a Daniel A. OLIVER-LALANA (eds.). The rationality and justification of legislation: essays in legisprudence. New York: Springer, 2013, s. 8.

60 Ibid., s. 9.

61 KNAPP, Viktor. Teoretické problémy tvorby československébo práva. Praha: Academia, 1983, s. 111. 
probíhající v orgánech moci zákonodárné, ale podílí na něm mnohem více subjektů (částî) veřejné moci. Přestože je $\mathrm{z}$ jeho prrístupu patrný prŕklon $\mathrm{k}$ racionálně-technicky vnímanému procesu legislativy, podíl tvưrčí činnosti nijak nevylučuje. Pokud zdůrazňuje nezbytnost používání legislativní techniky, připomíná její význam pro pochopení toho, jak bude výsledná právní norma interpretována. ${ }^{62}$ Nijak však nesměřuje $\mathrm{k}$ formalistickému pojetí tvorby práva jako procesu, který nepřipouští žádný podíl tvưrčí složky. Z Knappova pojetí (byt' to nevyjádřil přímo) plyne dojem, který je blízký závěrům shora zmíněného Dominiqua Rémyho ${ }^{63}$ odkazujícího na dílo rakouského urbanisty Camilla Sitteho Der Städtebau nach seinen künstlerischen Grundsätz̨en. ${ }^{64} \mathrm{I}$ přes mnohá technická omezení a nezbytnost funkčnosti zbývá v urbanismu stejně jako v tvorbě práva dost prostoru pro tvůrčí činnost. Alespoň v rozsahu uspokojujícím všechna omezení a požadavky. Z tohoto pohledu má tvorba práva blízko k pojmu Gesamtkunstwerk, jak jej rozpracoval Richard Wagner, a který chápal jako spojení více jednotlivých umění dohromady v jednom díle. ${ }^{65} \mathrm{I} v$ prípadě právního předpisu je nepochybné, že se v něm pojí více činností dohromady proto, aby se jednalo o funkční výsledek.

\section{Pilotní zjišt'ování}

Výše jsme zjistili, že je velmi obtížné, ne-li přímo nemožné, identifikovat př́stup, který by charakterizoval tvorbu práva jako ryze mechanickou činnost, která je ryzí formalistickou činností, bez jakýchkoli relevantních tvůrčích prvků. Mnohem obvyklejší je tvorbu práva charakterizovat jako činnost spojenou jak s racionalitou, tak s kreativitou. Racionalita procesu a jeho podřízení rozumným požadavkům, včetně předpokladu řádného mechanismu príijímaní právních předpisů (tedy procesů zajišt’ujících jejich platnost), nekoliduje s př́itomností tvưrčích prvků v samotném psaní či kompozici normativního textu. Můžeme také konstatovat, že podle Jeremy Benthama se v nomografii, tedy formě diskursu, kterou nadřízení sdělují podřízeným určený způsob jejich chování, spojuje véda a umění. ${ }^{66}$ Je to činnost, která nezbytně vyžaduje znalosti metod (postupů psanî) a znalosti objektu regulace, ale také vyžaduje tvưrčí př́istup při formování normativního textu. To koneckonců vyplývá i z jedné výpovědi legislativce získané v pilotním šetření: „Legislativa je sociálni kompetence, k.terá se nedá naučit. Je to zkušenost, k.terá je založená na budováni sociálních vazeb." V tom je prítomen jeden za základních prvků tvorby práva, tj. jeho společenské pojetí, vyžadující koordinaci více subjektů, jejichž záměry nutně nemusí být identické, a jejichž prŕstupy a postupy se mohou v jednotlivostech lišit.

62 KNAPP, Viktor. Teoretické problémy tvorby československého práva. Praha: Academia, 1983, s. 191.

63 RÉMY, Dominique. Légistique: L'art de faire les lois. Paris: Romillat, 1994, s. 15.

64 Viz např. český překlad SITTE, Camillo. Stavba měst podle uměleckých zásad. Praha: ABF, 1995.

65 WAGNER, Richard. Das Kunstwerk der Zukunft. Leipzig: Otto Wigand, 1850, s. 32.

66 BENTHAM, Jeremy. Nomography. In: BOWRING, John (ed.). Works of Jeremy Bentham. Volume III. Edinburgh: William Tait, 1843, s. 233. 
Zjišt'ování symbolického prostředí, ve kterém se pohybují legislativní experti, se nutně musí soustředit na jejich sebeidentifikaci - jeví se jako významné identifikovat, jak legislativní experti chápou sami sebe a svou činnost, včetně toho, jakou metodologii interpretace jsou schopni při své činnosti reflektovat. Zde se opět vracíme k tzv. anticipované interpretaci, ${ }^{67}$ protože uvědomění si toho, jak budou adresáti následně normativní text (právní předpis) interpretovat, legislativní práci výrazně ovlivňuje. $\mathrm{K}$ tomu je žádoucí uvědomit si také roli publika (adresátů) a přizpůsobit jeho očekávání nejen jazykovou stránku, ${ }^{68}$ ale celý proces vzniku. ${ }^{69}$

Výše jsme uvedli, že tvorba práva, psaní textu, má svá kodifikovaná pravidla, snad je ale už jasné, že zájmem výzkumu není popis a kritické zkoumání těchto pravidel. Je to naopak snaha navrhnout metody zkoumání toho, jak se tato pravidla odráží na praxi psaní, ale jak výsledný text ovlivňují i další externí faktory. Jinými slovy, naším cílem je zkoumání sociální praxe, první vhled do složitého pole, ve kterém jsou právní texty psány, abychom mohli navrhnout jeho další průzkum. V pilotní studii se tedy ptáme mimo jiné na to, jak legislativci chápou svou práci, co vše pro ně představuje a jaké významy do ní vkládají.

Pro studium významů jednání i věcí nabízí sociálním vědám nástroje především tzv. kvalitativní výzkum. Než se pustíme do podrobnějšího popisu naší studie, dovolíme si pár slov o principu toho výzkumu. Sociálně vědný výzkum je běžně - především v učebnicové literatuře ${ }^{70}$ - rozdělován do dvou základních větví. Výzkumu kvantitativního, který pracuje s hromadnými daty, bud' číselnými, nebo takovými, která lze do numerických hodnot převést. Tzv. kvalitativní výzkum s takovými daty nepracuje. Jeho závěry proto nejsou zobecnitelné, nelze je na rozdíl od hromadných statisticky zpracovávaných dat generalizovat na velké populace. Nabízí ale možnost postupného vhledu do menších společenství, hledá vysvětlení sociální reality u aktérů samotných. ${ }^{71}$

To je zásadní rozdíl v samotném základu přístupu k sociální realitě. Aplikace dotazníkového šetření a jiných kvantitativních metod, kterými jsme schopni generovat velké datové soubory pro statistickou analýzu, předpokládá, že máme o společnosti, či o jejî části, která spadá do našeho výzkumného zájmu, už předem nějaké vědomosti, či alespoň předpoklady. Je to metoda, ve které společnost popisujeme vlastními slovy, odbornými

67 BOHÁČ, Radim et al. Legislativní proces (teorie a praxe). Praha: Tiskárna Ministerstva vnitra, 2011, s. 45.

68 ŠÍN, Zbyněk. Tvorba práva: pravidla, metodika, technika. 2. vyd. Praha: C. H. Beck, 2009, s. 152; KOŘENSKÝ, Jan. Tvorba právních předpisů a komunikativní problémy jejich uplatňování. Slovo a slovesnost, 1995, roč. 56 , č. 4 , s. $267-275$.

69 SMEJKALOVÁ, Terezie a Martin ŠKOP. A Concept of a Reader in Legislation Drafting. In: ŠTĚPÁNÍKOVÁ, Markéta et al. (eds.). Argumentation 2017. Brno: Masarykova univerzita, 2017, s. 51-69.

70 Např. CRESWELL, John W. Research design: Qualitative, quantitative, and mixed methods approaches. Los Angeles: Sage, 2014; DENZIN, Norman K. a Michael D. GIARDINA. Qualitative inquiry through a critical lens. New York: Routledge, Taylor\&Francis Group, 2016.

71 Srov. např. téma hustého popisu a hledání významu v jednání in GEERTZ, Clifford. Interpretace kultur: vybrané eseje. Praha: Sociologické nakladatelství, 2000, Studie. 
termíny, které se snažíme překládat tak, aby jim adresáti dotazníků rozuměli a my měli alespoň nějakou jistotu, že získáváme odpovědi opravdu na to, na co se ptáme. Jsme $\mathrm{v}$ tomto výzkumu odborníky, kteři aplikují vlastní poznávací měřítka na svět, kterému rozumí.

V tzv. kvalitativním výzkumu naopak výzkumník hledá odpovědi na své otázky u sociálních aktérů samotných, protože předpokládá, že zatímco on jejich světu nerozumí, oni jsou na něj odborníci. Je to ovšem odbornost, která často není, na rozdíl od odbornosti vědecké a potvrzené kvalifikační zkouškou, uvědomovaná. To ovšem nic nemění na tom, že výzkumníci v takto nastaveném výzkumu předpokládají, že jestli někdo rozumí světu, který je zajímá, pak jsou to ti, kdo v něm žijí a utvářejí ho. Výzkumníci jsou v těchto světech pouze cizinci, kterým je zkušenost a významy zprostředkovávána. ${ }^{72}$ Jejich rolí pak je, co nejlépe přeložit svá zjiššční do jazyka vědy a obohatit tak její poznání. Tento přístup k poznávání světa jsme zvolili my.

Oba dva př́stupy nabízejí mnoho výzkumných metod, kterými lze data shromažd’ovat. Jednou z relevantních při studiu praxe lidského jednání je metoda pozorování. V závěru textu naznačíme i to, jak by bylo možné tuto metodu využít v našem konkrétním případě. S ohledem na téma výzkumu, kterým je především práce s textem a psaní jako takové, jsme zvolili klasickou metodu hloubkových rozhovorů. Jejich výhodou je především to, že jakkoli výzkumníci nastolují jejich témata, zůstává zde při citlivém vedení stále dost prostoru pro to, aby se participanti tázajících doptávali, navrhovali vlastní témata a někdy je přímo vybízeli k diskuzi. ${ }^{73}$

Rozhovory se skládaly ze dvou částí. První z nich se zaměřovala na samotný proces psaní, druhá pak na možnosti interpretace právního textu ${ }^{74}$ V následujících řádcích budeme vycházet pouze z části, ve které výzkumníci a výzkumnice hovořili s participanty a participantkami výzkumu o jejich práci a jejím průběhu. Rozhovor se skládal z pěti tematických částí, ve kterých jsme se ptali na celý průběh tvorby textu a jeho hlavní momenty, na aktéry, kteři psaní ovlivňují, na adresáty textu, na čistě praktické stránky psaní (např. pracovní podmínky) a na vztah k vlastní práci. Je třeba říci, že tento

72 HAMMERSLEY, Martyn a Paul ATKINSON. Ethnography: principles in practice. London: Routledge, 2007. DOI 10.4324/9780203944769

73 Srov. KAUFMANN, Jean-Claude. Chápajicí rozbovor. Praha: SLON, 2010.

74 Limity vedení interdisciplinárního výzkumu na poli jiné odbornosti nemáme možnost v tomto textu rozebírat. Alespoň poznamenáváme, že právě druhá část rozhovoru se ukázala jako jeden z problematických výzkumných úkolů. Je to právě otázka srozumitelnosti, kterou musí výzkumník řešit v každém poli, ve kterém bádá: rozumím správně svým komunikačním partnerům? Chápu přesně to, co se mi snaží říci? Ve výzkumu právního pole, $\mathrm{v}$ situacích, kdy byl u rozhovoru př́tomen pouze výzkumník neškolený v právu, se ukázalo, že nejenom že není schopen rozumět všemu, o čem právníci hovoří, ale především participanti mají zásadní problém s překladem do jiného než vlastního jazyka, jakkoli nejde o jazyk cizí, ale prostě obecný. Je to rys, který stojí za další studium už proto, že srozumitelnost je jedním z důležitých kritérií právního textu. 
text se zakládá především na analýze vstupních šesti rozhovorů, ${ }^{75}$ jejichž sběr pak dále pokračoval a byl průběžně upravován v návaznosti na průběžné výsledky. Komunikační partneři - zejména vzhledem k tomu, že se nejedná o kvantitativní šetření - byli voleni z legislativních expertů působících na Ministerstvu školství mládeže a tělovýchovy, Ministerstvu vnitra, Ministerstvu dopravy a Ministerstvu spravedlnosti. Záměrně byli vybíráni tak, aby reprezentovali různé pozice (začínající legislativec, zkušený legislativec, vedoucí odboru, legislativec na nejnižší pozici atp.), abychom mohli pokrýt co nejvíce aspektů legislativní práce, samozřejmě bez ambice činit z toho obecné závěry platné pro všechny legislativce.

\section{Analytická část}

$\mathrm{V}$ následujícím textu se budeme zabývat především tím, jak legislativní experti popisují svou práci. Zdůrazňujeme především ty jevy a momenty, které se dle první analýzy zdají být klíčové pro to, jak právní text ve výsledku vypadá, tedy ty prvky celého procesu, kterými by se měl zabývat hlouběji další výzkum. Budeme se tedy práci legislativců věnovat ze dvou hledisek, které lze snadno vyjádřit dvěma otázkami: Jaká je povaha psaní právního textu? a Jaká je povaha práce legislativce? Odpovědi na tyto dvě otázky spolu samozřejmě souvisí, současně ale vypovídají o dvou rozdílných věcech. První otázka směřuje k pochopení toho, co to vlastně je psaní - jakou povahu tato činnost má, jak ji participanti popisují, co jsou důležité fáze psaní atd. Odpovědi na druhou z těchto otázek pak nabízí vhled do toho, jak chápou legislativci svou práci nikoli jako „psaní, ale jako pozici a aktivitu, která je součástí většího celku tvorby práva, respektive sociálního pole s různými aktéry. Jinými slovy, naší snahou je pochopit psaní nejen jako specifickou odbornou aktivitu, ale také jako specificky zakoušenou pracovní pozici.

\subsection{Psát text}

V tomto textu se budeme zabývat výhradně psaním normativního textu. Součástí práce legislativce je samozřejmě i psaní mnoha dalších textů - důvodových zpráv, dopisů, vysvětlení, stanovisek, pripomínek atp. Naším cílem je ale popis toho, co, zjednodušeně řečeno, znamená psát text zákona. Z hlediska potřeb budoucího výzkumu jsme se snažili definovat klíčové okamžiky celého procesu psaní a s nimi související klíčové aktéry. Zajímala nás také představa „ideálně“ odvedené práce. Ve všech těchto bodech jsme se setkali s, pro nás překvapivě, bohatou škálou odpovědí. Nejprve se zaměríme na povahu psaní jako takového, dále pak na otázku klíčových momentů.

75 Vzhledem $\mathrm{k}$ tomu, že jednalo pouze o pilotní studii vedoucí ke vzniku metodologie, a vzhledem $\mathrm{k}$ tomu, že se jedná o kvalitativní výzkum, jehož cílem není podat data zobecnitelná na populaci, ale pouze ukázat postoje legislativních expertů, a jejich vlastní popis legislativní práce, je možné pracovat i s tak nízkým počtem rozhovorů. Na druhou stranu jsou tato zjištění dále ověrována a prohlubována $\mathrm{v}$ dalších rozhovorech, a to včetně rozhovorů s některými členy Legislativní rady vlády. 


\subsubsection{Co je to psani a čim se rídí}

Není nikterak překvapivé, že i v rozhovorech, jež jsme vedli, se objevuje jistá tenze mezi tím, zda je psaní legislativního textu aktivitou tvưrčí a autorskou, či zda jde o činnost podléhající přesným pravidlům, při které je eliminována možnost osobnostního vkladu autora. Jinými slovy, zda jde o činnost, ve které by autor měl být v zásadě neviditelným tvưrcem, který textem zprostředkovává vưli zadavatelů. Sociální realita se obvykle netvaruje do podobných ideální typů - proto jakkoli se oba tyto póly ve výpovědích objevují, neobjevují se nutně jako dva konce jedné škály. Nevidíme na jedné straně volnomyšlenkářské kreativce a na druhé straně pravidla rigidně dodržující „stroje na psaní. Naopak můžeme identifikovat znaky, které odpovídají více či méně jednomu nebo druhému př́ístupu, u jednoho či jedné participantky, ovšem s různým důrazem, respektive v různých kontextuálních situacích. Setkáváme se především s tím, že legislativci řeší formální otázky, které ale souvisí s povahou obsahu.

Př́kladem takového řešení může být hledání označení a s ním souvisejícího správného zařazení části zákona do jeho textu, jak jej popisuje jedna z participantek: „Př́klad by mohl být $\int 45$ aa. Legislativni pravidla o tom mlčí, ale takble se to nedělá, protože to je prostě zhovadilost. No dobré, bud’ tam dáme označovaci zhovadilost, nebo to prostě bude o padesát paragrafú dál, kede to nikedo nenajde. Takž̃e jak? Ta úvaha byla... Kdyžjüm (tèm, kterých se daná cást quákona týká) to hodime na konec toho predpisu, bude to pro ně neprèhledné. Takže mè zajimal ten, kdo by asi chtěl takovou službu vykonávat a kde by to hledal. "

Ukazuje se, že i hledání správného odstavcového členění lze chápat jako tvưrčí činnost, která vede $\mathrm{k}$ tomu, aby byl text srozumitelný čtenáři. Ostatně právě srozumitelnost je klíčovým požadavkem na kvalitu textu - a její zachování (či nastolenî) vyžaduje schopnost představit si toho, kdo je adresátem textu. Kdo s ním bude pracovat a jak. Téma srozumitelnosti a publika je dalším důležitým okruhem narací našich komunikačních partnerů, dříve než se k němu dostaneme, krátce se zmíníme o jiném aspektu, který zmiňuje výše uvedený úryvek.

Legislativní rada vlády respektive Legislativní pravidla vlády jsou základními vodítky pro psaní každého textu zákona. ${ }^{76}$ Věta „Legislativní pravidla o tom mlčrc je pak důležitou poznámkou odkazující k zajímavé zkušenosti, na kterou nějakým způsobem narážejí všichni legislativní experti, se kterými jsme vedli rozhovory. Některá pravidla psaní textů nejsou zapsána a přesto se jimi legislativní pracovníci a pracovnice řídí. Jejich zkušenost, která je podstatnou součástí jejich odbornosti (ano, není to obráceně), jim říká, které formulace a formální úpravy mohou být Legislativní radou vlády akceptovány, a které budou prríčinou, že se text vrátí k přepracování.

76 Legislativní pravidla vlády jsou dokumentem, který zmiňují všichni komunikační partneři a partnerky. Dalšími zmiňovanými formálními pomocníky jsou pak pravidla českého pravopisu, nebot' text musí samozřejmě odpovídat jejich aktuální podobě, a dále právnické informační systémy, zmiňované prèedevším jako zdroj dohledávání relevantních informací, ale také jako inspirační zdroj např. ve věci precizní formulace. 
Pravidla stanovená formálně (Legislativní pravidla vlády) i neformálně Legislativní radou vlády (její rozhodovací praxî) nebo legislativními zvyklostmi jsou tedy jedním z měřítek „správnosti“ normativního textu. Jiným je výše zmíněná srozumitelnost, která je např. stanovena čl. 2 odst. 2 písm. c) Legislativních pravidel vlády jakožto jeden z požadavků kladených na tvorbu právních předpisů, avšak z rozhovorů není patrné, že by se tím toto téma vyčerpávalo, či že by bylo zcela jasné, co se srozumitelností rozumí. Téma srozumitelnosti, vysvětlení toho, co si vlastně legislativci představí, když říkají, že text musí být srozumitelný, zaslouží ještě hlubší výzkumnickou pozornost, nebot' se nejedná o pojem, který by byl popsán vyčerpávajícím zpo̊sobem. Na základě doposud provedených rozhovorů víme, že představa srozumitelnosti úzce souvisí s představou o publiku, kterou ti, kdo texty píší, mají. Podstatné je ale uvědomit si, že publikem legislativců není zdaleka pouze adresát zákona, na kterém pracují. To by byla ideálně typická situace, ve které se nenacházejí. Při své práci musí zohledňovat požadavky mnoha jiných aktérů, které se ve větší či menší míre na podobě textu opět podepisují: Samozřejmě je zde důležitá role nadřízeného, který za práci odpovídá. Dále je zde zadavatel a tvưrce věcného záměru zákona, se kterým musí legislativec bud' osobně, nebo zprostředkovaně text konzultovat. Dále je to zmíněná Legislativní rada vlády a ostatně také členové obou komor parlamentu, který bude text schvalovat. V tomto výčtu se zdá být adresát, na kterého bude obsah normativního textu dopadat, či který se jím bude řídit a který bude muset textu rozumět, jako jeden $z$ posledních $v$ pořadí. A to především proto, že se k textu opravdu jako jeden z posledních dostává (pokud vůbec).

Ukázalo se dále, že legislativci nejsou nutně za jedno ani v tom, co požadavek obecné srozumitelnosti vlastně znamená. Od představy, že textu by měl rozumět opravdu každý, po představu, že obecná srozumitelnost se nakonec týká především aktérů, kteří se pohybují v právním poli. To je př́stup, který skupinu těch, co právnímu textu rozumí, chápe přece jenom poněkud zúženě, schopnost porozumění vidí jako specifickou kompetenci získanou bud' studiem práva a příbuzných oborů, nebo po zaškolení, které poskytnou konkrétnímu publiku k tomu určení odborníci. Schopnost rozumět právnímu textu tedy není něco samozřejmého, ale jde o nesamozřejmou vlastnost, kterou je třeba si osvojit. ${ }^{77}$ Posledním bodem, který souvisí se „správnosti““ textu a považujeme za nutné jej zmínit, je otázka ideálního právního textu. Jak jsme řekli výše, jeho předpokladem je srozumitelnost, jakkoli není zcela jasné, co přesně tato kategorie znamená. Během výzkumu jsme se však setkali se zajímavou polemikou na téma ,ideálního textu“ “ ${ }^{78}$ Nikdo z našich participantů a participantek nezpochybňoval, že mohou existovat špatné předpisy:

77 Což jinými slovy znamená, že v některých př́padech je nutné být společností $\mathrm{k}$ tomu „rozumět právu“ př́mo legitimizován.

78 Ideální právní text není nijak definován a v rozhovorech šlo o to zjistit, zda legislativní experti mají o takovém textu konkrétní představy, či zda jsou schopni ř́ci, jaká kritéria (obsahová nebo formálnî) má ideální text splňovat. Zda je to např́klad text, který je zcela srozumitelný a nijak přitom nerezignoval na věcnou a právní správnost. 
ty, které nejsou jednoznačné, které lze vykládat dvojím způsobem, ve kterých se mohou nalézt mezery, popř́padě takové, které nezapadají do systému práva a tím způsobují problémy. Objevil se ale zajímavý moment, ve kterém se legislativec s relativně dlouhou praxí a zkušeností se psaním různých typů zákonů ohradil vưči možnosti, že existuje lepší než dobrý právní text: „Pokud píse (legislativec) srozumitelně a bez chyb, tak je jeho práce ve výsledku úplnè stejná jako práce jeho kolegů, k.teř́ dokáǎou psát srozumitelně a bez chyb. "Toto poměrně striktní vyjádření lze interpretovat jako přijetí představy, že nejvyšší dokonalostí je schopnost téměř mechanicky dodržet nastolený formální standard.

Vedle těchto kritérií, která zaručují správnost textu, a nástrojů, které jí napomáhají, se pak můžeme ptát na to, co vše je vlastně psaní. Z narací našich komunikačních partnerů a partnerek vyplývá, že nejde pouze o samotnou tvorbu textu, ale že součástí procesu psaní je i neustálé vyjednávání s mnoha aktéry. Jedná se v podstatě o ty, kteří jsou současně označováni jako jisté typy publika. Zmiňujeme je zde ještě jednou proto, že se ukazuje, že toto vyjednávání může mít charakter jistých rutin, jakými jsou např. předpřipravené formáty dopisů, které se rozesílají zainteresovaným stranám. Rozhodně ale platí, že „psaní“ fakticky znamená také vyjednávání, diskutování a zpřesňování obsahu textu s dalšími aktéry.

\subsubsection{Klićové momenty psani normativního textu}

Zdá se samozrejmé, že první odpovědí na hledání klíčových momentů v psaní normativního textu prakticky u všech tázaných byl jednoduchý popis legislativního procesu: zadání, první čtení, druhé čtení, schvalování, pozměňovací návrhy atd. Při hlubším dotazování se však ukazuje, že se jednotliví legislativci liší v tom, jaký význam jednotlivým předepsaným fázím tohoto procesu přikládají. Dokonce se liší i v tom, kdy považují svou práci na zadání za ukončenou. Zatímco někteří ji jako ukončenou vidí ve chvíli, kdy text odchází do schvalovacího procesu, jiní popisují jako faktický závěr až chvíli, kdy je text schválen Parlamentem. Jeden z participantů nap̌r. uváděl jako specifický završující rituál poslední kontrolní čtení před tiskem. ${ }^{79}$

Přes tyto rozdíly v percepci je třeba říci, že lze ve výpovědích identifikovat dvě podstatné události prípravy textu, které zásadně ovlivňují jeho výslednou podobu - at' už formální či obsahovou. Z výše řečeného vyplývá, že jedním z nich je předložení textu Legislativní radě vlády, což je moment, ke kterému se ve svých výpovědích nějakým způsobem vztahují všichni participanti výzkumu. Ještě stěžejnější chvílí je pak tvorba věcného záměru, která fakticky předchází práci na textu samotném.

79 Je zajímavé, že rozhovor s aktérkou, která byla legislativcem, v současné době je ale ředitelkou jednoho z legislativních odborů ministerstva ukazoval, že ji mnohem méně zajímají podobné formální aktivity - tuto formu kontrolního čtení dokonce označila za zbytečnou - naopak kladla důraz na obsahovou stránku textu. Pravděpodobně právě proto, že texty sama nepíše, neřeší souvislost formální a obsahové stránky tak silně, jako to vidíme u praktikujících legislativců. 
Zdá se, že legislativci chápou kvalitu věcného záměru jako klíčový prvek, který ovlivní kvalitu jejich vlastní práce. Podobně, jako se nám dostalo naprosto ambivalentních popisů toho, kdy je práce legislativce ukončena, kdo je jejím adresátem a jaká jsou pravidla psaní legislativy, dostalo se nám i různorodého popisu zkušenosti s věcným zadáním (obvykle věcným záměrem). Od textů, které jsou prakticky paragrafové znění, jež musí legislativec upravit a provést kontrolu jejich správnosti, po texty, které vyjadřují opravdu pouze efemérní záměr, a jejichž jazyk se nemusí jazyku norem ani blížit. Na povaze těchto vstupních textů, respektive na př́stupech $\mathrm{k}$ nim, lze pak dobře ilustrovat to, co je naším druhým zájmem, tedy pochopení toho, co to znamená být legislativcem.

\subsection{Být legislativcem}

$\mathrm{V}$ zásadě můžeme konstatovat, že mnoho o tom, co znamená být legislativcem, bylo řečeno již v předchozí části věnované otázkám toho, co je to psaní. Pokusíme se tedy to, co bylo naznačeno, krátce shrnout - rozdíl je v tom, že zatímco výše jsme se věnovali tomu, jak legislativci charakterizují činnost, kterou vykonávají, nyní se posouváme $\mathrm{k}$ tomu, jak vidí sami sebe. $\mathrm{V}$ naracích našich komunikačních partnerů a partnerek se objevilo několik označení, která vyjadřují povahu práce legislativců a vystihují fakt, o kterém jsme se zmínili výše. Psaní zákonů je mnohem spíše vyjednáváním, než samotným tvořením textu. A v průběhu tohoto procesu se tak legislativci dostávají do rozdílných roli ${ }^{80}$. Tyto jsme odhalili ve výpovědích našich participantů a participantek: ${ }^{81}$

V první fázi práce je především analytikem. Musí zhodnotit co přesně je cílem návrhu, kdo jsou dotčení aktéři a v jakých oblastech se projeví, a to záměrně, ale také nezáměrně. Legislativec musí rozložit záměr na jednotlivé části, a ty pak převést do praxe práva.

Po té, co návrh takto analyticky rozloží, je další ze zmiňovaných rolí role blídače. Musí dojít k posouzení, zda jsou návrhy a požadavky předložené ve věcném záměru oprávněné a dokonce, zda nejsou protiprávní.

Ve chvíli, kdy je jasné, že je vůbec možné začít podobný návrh zpracovávat, stává se legislativec garantem kvality textu, především toho, že bude odpovídat svému okolí, tedy že bude odpovídat ostatním zákonům, a současně opět pohlídá, kde všude se zákon projeví a co vše tedy bude nutné upravit. ${ }^{82}$ Výraz garant ale také vyjadřuje záruku, že budou projednány všechny připomínky a návrhy, které se k novému textu během veškerých stupňů připomínkování mohou objevit.

80 To, zda projdou všemi uvedenými rolemi, do značné míry souvisí právě s kvalitou či podobou věcného záměru.

81 Jsou to skutečně pouze označení, která své roli legislativní experti přisuzují. Byt' teoreticky můžeme jejich působení označit i jinak, setkali jsme se pouze s těmi níže uvedenými.

82 Je zajímavé, že komunikační partneři a partnerky nijak zásadně nesouhlasili s přirovnáním k jazykovým korektorům či editorům. Právě moment neustálého srovnávání s okolím podle nich odlišuje práci legislativce od těchto jazykových profesí. 
Konečně posledním označením, kterého se pozici legislativce dostalo, je dokončovatel. $\mathrm{Na}$ této úrovni se pak jednalo o snahu vyjádřit nejenom to, že jde o práci, která musí obsahově odpovídat svému okolí (součást práce garanta), ale současně o práci, ve které musí být dodrženy všechny formální náležitosti, odstavce musí být na svých místech, nesmí se objevit chyba v číslování paragrafů, nesmí chybět odkazy na správné předpisy atd. Jinak řečeno, právní text musí být přesný.

Pro každou podobnou analýzu je důležité zachytit nejenom to, jak se aktéři vidí a jaké obsahy vkládají do svých činností, ale také to, jak se neoznačují. Je jistě důležité, že žádný z námi dotazovaných se necítil být autorem textů, které sám píše: „Bèhem let jsem se zcela oprostil od toho, co zcela prirozené napada každého autora. Totiž to, že ten text je produktem néjaké mé vnitrni jedinečnosti a osobitosti a ̌̌e jsem jeho skutečným, plnohodnotným autorem, jako kdybych psalpoezii. Já to tak v žádném prípadé nevnímám, jsem schopen se oprostit od tohoto autorskébo vątabu k tomu textu. Myslim, že je to tak v porádku - nepiši ani román, poezii, dokonce ani odborný článek ri pojednání. Pišsi právni predpis. Samozrejejě nikdy nejsem výlučným autorem toho textu. "Tím samozřejmě není chápáno popření prrípadných tvưrčích prvků, ale ukazuje to vztah toho, kdo piše k výsledku své práce, který chápe neosobně a udržuje si od něj odstup.

Toto vyjádření přesně ukazuje na hlavní rys, který zastřešuje všechny výše zmíněné role legislativce. Zdá se, že legislativci sami sebe vidí především jako nástroj systému, který má zaručit, že jeho jednotlivé součásti budou do sebe dobře zapadat. Jedním z hlavních rysů těchto nástrojů pak je, že za systém nemluví, ale pouze připravují podklady, popř́ípadě prímo ty aktéry, kteří jsou zmocněni mluvit - své nadřízené, poprrípadě jejich nadř́zené.

\section{Závěr}

Jako relevantní se ukázalo zjišt'ování toho, jak legislativní experti popisují sami svou práci, včetně toho, jak svou práci interpretují a jak chápou a popisují svou pracovní pozici (analytik, hlídač, garant, dokončovatel, nebo obecně nástroj). Tento př́stup umožní identifikovat jejich prrístup k samotnému procesu psaní (tvorby), zejména v tom ohledu, zda se jedná o tvưrčí činnost, plně formalizovaný postup skládající se z rutinizovaných činností, ve kterém není pro tvưrčí činnost prostor, př́padně, zda se jedná o tvưrčí činnost, která je však silně regulována pravidly (bez ohledu na to, zda právními nebo jinými sociálními pravidly). Ukázal se také rozdíl mezi teoretickými koncepty, které se zřetelně přiklánějí k pojetí tvorby práva jako činnosti, která zahrnuje i výrazné tvưrčí prvky a zjištěními z pilotního šetření ( $\mathrm{z}$ hloubkových rozhovorů). Legislativní experti svou činnost vnímají dominantně jako formální - dokonce jsou ochotni popsat sami sebe jako nástroj. Tento verbalizovaný popis své role však není potvrzen dalšími částmi rozhovorů. V nich se objevují prvky, které takové striktně formální pojetí psaní návrhu právního předpisu narušují. Tato eroze se projevuje např́klad tím, že konec psaní návrhu může znamenat až jeho schválení orgánem s legislativní pravomocí a případně publikací. Takové zaujetí 
pro kariéru výsledku se ovšem ve striktně formálním prostředí nedá očekávat. Ten, kdo se tak projevuje, nemůže sám sebe zcela chápat jako nástroj. V rozhovorech jako celku se proto setkáme s pojetím, které popisuje - spíše neintencionálně - psaní jako více subjektivní (tvưrčí) proces. Ovšem bez plně projeveného autorství a vždy podřízeného obsahu a formální stylu normativního textu.

Jako relevantní se v tomto ohledu jeví také využití zkoumání narativů, zejména s tím ohledem, že ve všech možných prŕstupech k legislativní činnosti, vždy existuje pro narativitu prostor - zejména $\mathrm{v}$ tom, jaké významy jsou přisuzovány chování, které má být regulováno, v konstrukci očekávání adresátů, očekávané interpretaci, promýšlení možných verzí regulovaného jednání $\mathrm{v}$ závislosti na jiných přístupech $\mathrm{k}$ regulaci (včetně promýšlení možných reakcí „obvyklých podežrelých“, tedy promýšlení reakcí adresátů, kteří pravidla porušujî), ale také ve zvažování dopadů používání jednotlivých slov a slovních spojení, včetně zvažování, zda nenastal prostor pro větší srozumitelnost porušit některá metodologická doporučení či pravidla pro konstrukci normativního textu.

Při empirickém zkoumání tvorby práva je vždy nutné pamatovat na to, že př́íprava legislativních návrhů probíhá $\mathrm{v}$ mnoha různých podobách a formách. ${ }^{83}$ Nemá jednolitou podobu, která by byla identická na všech ministerstvech - na některých může proces probíhat v expertních týmech, na jiných je zcela svěřena legislativnímu odboru. Tomu odpovídá i různé postavení legislativců, resp. různé charakteristiky, které své činnosti sami přisuzují. S různou činností a s různým postavením legislativců se liší také přístup k jednotlivým prvkům legislativní techniky. Při šetření je nutné vzít v úvahu, že některé postupy, které slouží ke zvyšování srozumitelnosti (př́padně samotná srozumitelnost) musí ustoupit kompromisu, časovému tlaku nebo politickým vlivům. ${ }^{84}$ Někdy je také relevantní, že legislativci žádné interpretační postupy neznají a jednají intuitivně či v lepším př́ípadě rutinně. ${ }^{85} \mathrm{~V}$ tomto případě je však nutné zjistit, jak skutečně postupujî a tyto popisy náležitě analyzovat a př́padně je propojit s teoretickými či metodologickými koncepty.

Dále lze rríci, že při zkoumání administrativních fází procesu tvorby normativního textu se jednotlivé dílčí fáze, jejich obsah a konkrétní př́stup k práci jeví jako velmi ambivalentní. Neexistuje jeden správný styl či jeden správný postup. Rovněž výsledek, jakož i samotná legislativní práce, jsou často ovlivněny vnějšími faktory, na které legislativní expert nemůže mít vliv. Podstatné pro vytváření návrhu právního předpisu je např́íklad věcné zadání nebo věcný záměr. Ten (navzdory Legislativním pravidlům vlády, hlava I)

83 NOURSE, Victoria F. a Jane S. SCHACTER. The Politics of Legislative Drafting: A Congressional Case Study. New York University Law Review, 2002, roč. 77, č. 3, s. 583.

84 Ibid.

85 Ibid.; př́ipadně GLUCK, Abbe R. a Lisa SCHULTZ BRESSMAN. Statutory Interpretation from the Inside - An Empirical Study of Congressional Drafting, Delegation, and the Cannons: Part I. Stanford Law Review, 2013, roč. 65, č. 5, s. 916. 
má dle výpovědí legislativních expertů kolísavou kvalitu, a to dokonce do té míry, že někdy vưbec neexistuje (!) či - právě proto, aby Legislativní pravidla vlády nemusela být dodržena - nese jiný název (např. teze). Jasná a striktně dodržovaná pravidla nemá ani samotné psaní. Navzdory tomu, že existují psaná pravidla a také pravidla nepsaná (napr. legislativní zvyklosti), která jsou legislativním expertům známa, avšak nejsou schopni je verbalizovat. To pochopitelně souvisí s dlouhodobou zkušeností, se znalostí prostředí, bezesporu se sociálním kapitálem, který si legislativci vytvář́.

V této souvislosti je nutné poznamenat, že velmi výrazný podíl zde má Legislativní rada vlády. Ta nejen posuzuje kvalitu a úroveň návrhů předkládaných vládou, ale také sděluje legislativním expertům, které návrhy nejsou přijatelné. Je to tedy orgán, který by měl mít jasná pravidla pro svou činnost a také stanovovat jasná pravidla pro legislativu. To by však předpokládalo skutečně profesionální orgán - nikoli co do kvality, nebot' skladba členů je odpovídající - ale co do formy činnosti. Legislativa má být dominantní náplní člen rady a mají za to být honorováni odpovídajícím způsobem. Pokud mají formulovat pravidla, která ovlivňují nejen formulaci, ale následně i interpretaci, nemohou se tomu (přes své schopnosti) věnovat jen částečně. Jako velmi užitečné se také jeví zkoumání samotné činnosti rady - zde by bylo na místě provést pozorování (nikoli zúčastněné pozorování, nebot' takový postup by kolidoval s etikou vědeckého zkoumání) a zjistit, jaké jsou standardní reakce členů rady, jak jsou determinovány a jaká sdělení jsou legislativcům adresována. To samozřejmě se snahou určit v takovém jednání pravidelnosti.

To by mělo být součástí dohadování se o (legislativních) konvencích. Tedy o konvencích stanovících, jaké texty nesou jaké ustálené významy (klišé), ${ }^{86}$ tak, aby normativní text se tvořil vždy stejným způsobem, a aby byl takto také interpretován. Jasná a unifikující činnost Legislativní rady vlády by měla působit jako jeden z článků hledání standardních forem komunikace mezi autorem (normotvůrcem) a publikem (adresátem - typicky reprezentovaným soudy). Výsledkem by měly být interpretační/normotvorné standardy a skutečný interpretační dialog.

Při zkoumání procesu tvorby a toho, jako legislativní experti využívají metody interpretace práva, se však ukázalo, že není jasné ani to, kdo je adresátem - respektive je jich mnoho a při jejich identifikaci neexistují jasná pravidla. Jako jisté se snad jeví jen to, že jej nelze ztotožňovat s nějakým anonymním pojmem lid, alespoň ve většině př́padů. Schopnost porozumět je vlastně chápána jako naučená kompetence, kterou rozhodně nemá každý, ale je nezbytné ji získat. Jaký obsah pak má pojem srozumitelnost, který je považován za nejpodstatnější kritérium správnosti psaného textu, tedy zůstává otázkou. Text je srozumitelný, když mu adresát rozumí, ale kdo tím adresátem vlastně je?

86 KNAPP, Viktor. Právní pojmy a právní terminologie (Právní pojmosloví a názvosloví). Státní správa: Bulletin Ústavu státni spráyy v Praže, 1978, č. 4, s. 21. 
Empirická šetření v oblasti administrativních fází procesu tvorby práva, vztahu intepretace a tvorby se dále objevují další oblasti, které by bylo relevantní zkoumat. Vzhledem k silnému vlivu na následné procesy psaní by bylo vhodné zaměřit se na procesy tvorby věcných zadání nebo skutečně věcných záměrů. Jak vznikají, jakou mají podobu a jak ovlivňují práci legislativních expertů? Jak probíhá vyjednávání mezi jednotlivými aktéry v legislativním procesu? 'Toto zkoumání má i zřetelně praktický význam, nebot' může napomoci identifikovat, jaké typy legislativců jsou efektivní, jaké jsou př́padně konfliktní a jaké nedosahují žádaných výsledků. S tím souvisí i zkoumání postavení legislativců na jednotlivých ministerstvech a jak se to projevuje v jejich práci. Relevantní se jeví více do tohoto výzkumu zapojit i Legislativní radu vlády a zjistit, jak probíhá její jednání a jak komunikuje s jednotlivými legislativními experty. V tomto př́ipadě však opět může dojít ke kolizi s etikou vědeckého bádání, nebot' přestože se zde směřuje k lidem, jakožto sociálním aktérům, ne vždy se může podařit výsledky plně anonymizovat (to je možné u legislativních expertů, kterých je více, ale obtížnější je to u několika členů rady). Zkoumání této části legislativního procesu tedy jednoznačně nelze považovat za ukončené. 